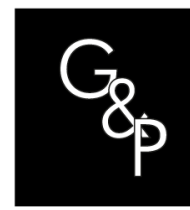

\title{
Competences of the Executive Secretariat in project management
}

\author{
Competências do Secretariado Executivo na gestão de projetos
}

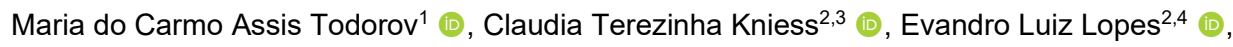 \\ Cibele Barsalini Martins ${ }^{5}$ (D) \\ ${ }^{1}$ Faculdades Metropolitanas Unidas - FMU, São Paulo, SP, Brasil. E-mail: madu4@hotmail.com \\ ²Universidade Federal de São Paulo - UNIFESP, São Paulo, SP, Brasil. E-mails: kniesscl@gmail.com; \\ elldijo@uol.com.br \\ ${ }^{3}$ Universidade São Judas Tadeu - USJT, São Paulo, SP, Brasil. \\ ${ }^{4}$ Universidade Nove de Julho - UNINOVE, São Paulo, SP, Brasil. \\ ${ }^{5}$ Universidade Federal de Santa Catarina - UFSC, Florianópolis, SC, Brasil. E-mail: cibele.martins@ifsc.br
}

How to cite: Todorov, M. C. A., Kniess, C. T., Lopes, E. L. \& Martins, C. B. (2021). Competences of the Executive Secretariat in project management. Gestão \& Produção, 28(3), e5181.

https://doi.org/10.1590/1806-9649-2021v28e5181

\begin{abstract}
This study aimed to analyze the perception of the project manager regarding the Executive Secretary's contribution in project management. The pursuit of competitive advantage has led organizations to be concerned with project management and the communication difficulties and a lack of leadership during the process are cited among the reasons that compromise project success. In order to relate the powers of the Executive Secretary with the competences of the project team, was used the Brazilian Curriculum Guidelines of the Executive Secretariat Course and the skill set proposed by the International Project Management Association, for the construction of a theoretical model, which was analyzed by structural equation modeling. The results showed that the Executive Secretary is a contributive member of the project management team who enables efficient management of projects. With this result, we found that project managers may seek Executive Secretariat support to achieve project success.
\end{abstract}

Keywords: Project management; Executive secretary; Skills; Structural equation modeling.

Resumo: Este estudo teve como objetivo analisar a percepção do gerente de projetos em relação à contribuição do Secretário Executivo no gerenciamento de projetos. A busca de vantagem competitiva levou as organizações a se preocuparem com o gerenciamento de projetos e as dificuldades de comunicação e a falta de liderança, durante o processo, são citadas entre as razões que comprometem o sucesso do projeto. Para relacionar os poderes do Secretário Executivo com as competências da equipe do projeto, foram utilizadas as Diretrizes Curriculares Nacionais do Curso de Secretariado Executivo e o conjunto de habilidades proposto pela International Project Management Association, para a construção de um modelo teórico, que foi analisado por modelagem de equações estruturais. Os resultados mostraram que o Secretário Executivo é um membro colaborativo da equipe de gerenciamento de projetos e permite o gerenciamento eficiente de projetos. Com esse resultado, constatou-se que os gerentes de projeto podem buscar o apoio do Secretário Executivo para alcançar o sucesso do projeto.

Palavras-chave: Gestão de projetos; Secretário executivo; Competências; Modelagem de equação estrutural.

Recebido em Dez. 18, 2019 - Aceito em Abr. 17, 2020

Financial support: None.

This is an Open Access article distributed under the terms of the Creative Commons Attribution License, which permits

unrestricted use, distribution, and reproduction in any medium, provided the original work is properly cited. 


\section{Introduction}

One of the biggest challenges for organizations is the project team's commitment to project management. At the beginning of project management, it was possible to execute successful projects, only defining time and costs (Thamhain, 1993; Magalhães et al., 2020). However, it is currently observed that this is not enough for the success of a project. It is necessary to manage teams and this is an art that involves great challenges. The success of projects today depends on multidisciplinary efforts, with the involvement of the entire project team (Thamhain, 2012; Moura, Carneiro, \& Diniz, 2018).

Project management has evolved to be more collaborative between leaders and team members, with the assurance of faster adoption of changes and benefits, if well executed (van der Vaart et al, 2012). The commitment of the project management (PM) team contributes to the project link between the corporation and the project stakeholders (Carvalho \& Rabechini, 2011).

The functions of the Executive Secretary (ES), and their importance to PM showed significant development in recent years with regard to preparation to meet the changing labor market (Leal, \& Moraes, 2017; Paes, \& Santiago, 2020). The ES training enables a professional to perform different tasks in different areas of the organization both private and public and use knowledge management to support decision-making (Souza, Maier, \& Maçaneiro, 2013; Carvalho et al, 2019; Snoeijer, Moreira, \& Martins, 2019; Moreira et al, 2020).

Since the ES creates a link between the members of a company, it is believed that the skills and profile of this professional can contribute directly to the success of projects, improving many aspects of communication (Piscopo \& Silveira, 2013), which is a factor of project failure (Kerzner, 2017; Vezzoni et al., 2013). However, the literature is still lacking in work to establish this association.

In a scenario in which there is a growing need for organizations to develop and improve $\mathrm{PM}$ and be aware that a major obstacle is the motivation of the team members (Carvalho \& Rabechini, 2011), it is necessary to deepen theoretical and empirical research, particularly the identification of core competencies and potential ES contributions in driving PM (Bíscoli \& Bilert, 2013).

In this sense, this article aims to answer the following question: what are the project managers' perceptions of the contributions of the Executive Secretary in project management?

In order to understand the presented problem situation, this study aims to analyze the perception of project managers as to the Executive Secretary contribution in project management.

Thus, this article is divided into four sections, besides this brief introduction. The first section presents the theoretical framework of PM, highlighting the skills of the project team and the Executive Secretariat professional. The second covers the methodological aspects of the study. The third section is the analysis of empirical data phase of the work, and finally, the last section presents the end of study considerations.

\section{Theoretical Framework}

Considering the central objective of this study, it is necessary to explore the context of project management and the powers of the Executive Secretary in project management. 


\subsection{Project management}

Concept designs have evolved in recent years following the maturity of PM in organizations. One definition is that a project is a temporary effort, progressive and unique (Project Management Institute, Inc., 2017; Shenhar \& Dvir, 2010; Winch, 2014; Bennet, 2017).

PM is a macro process that allows quick and efficient implementation of organizational strategy decisions. Project Management Institute, Inc. (2017) suggests processes should be focused on the most effective use of people involved with the project. Thus, it considers the development of project team skills that are important and necessary for project success (Carvalho \& Rabechini, 2011; Moura et al, 2019; Amaral et al, 2015). Design professionals should have the core competencies of team building, leadership, conflict resolution, technical expertise and planning, organization, entrepreneurship, management support, and good judgment to the correct allocation of resources (Kerzner, 2017).

Consequently, the central part of the complexity of the project is on teamwork and experience of members (Takey \& Carvalho, 2015). Communication difficulties and a lack of leadership during the process, caused by lack of experience and teamwork, are among the reasons that hinder projects (Araújo, \& Pedron, 2015; Moura et al, 2018; Oliveira et al, 2018), in addition to the difficulty in controlling anxieties and resistances, generated by change (Almeida \& Ramos Filho, 2018) and in solving problems (Lin et al., 2015) .

Some weaknesses of team members are in: i) leadership ability, because the lack of leadership hinders team communication; ii) technological skill: when team members have the necessary technological skills it reduces rework; and iii) coordination skills: lack of efficient coordination results in rework and miscommunication (Lu et al., 2014).

Communication management is a key and essential factor in the success or failure of a project. When communication is carried out effectively, it will ensure that the right information gets to the right person at the right time and in an appropriate manner (Kerzner, 2017).

\subsubsection{Competence in Vision for Project Management}

Competence "is a set of skills and technologies and not a single skill or isolated technology" (Hamel \& Prahalad, 2013, p. 34). As for Fleury and Fleury (2001), the individual competence comes from the person's characteristics, educational background, and professional experience. Competence means that the individuals "know how to act responsibly and recognized, which means mobilize, integrate, transfer knowledge, resources and skills that add economic value to the organization and social value to the individual" (Fleury \& Fleury, 2001, p. 187).

The IPMA Competence Baseline (ICB) developed the requisite competences for project professionals for the International Project Management Association (IPMA). As shown in Table 1, the frame is divided into three areas of competence (IPMA Brasil, 2012): 
Table 1. General Vision of the Elements of the Competences of projects teams.

\begin{tabular}{ccc}
\hline Technical Competences & Behavioral Competences & Contextual Competences \\
\hline $\begin{array}{c}\text { Success in the projects } \\
\text { management }\end{array}$ & Leadership & Orientation of projects \\
\hline $\begin{array}{c}\text { Stakeholders } \\
\text { requirement }\end{array}$ & Commitment and motivation & Orientation in programs \\
\hline Risks: opportunities and threats & Self control & Orientation to a portfolio \\
\hline Quality & Assertiveness & $\begin{array}{c}\text { Implementation of projects, } \\
\text { programs and portfolios }\end{array}$ \\
\hline Organization of projects & Casualness & Permanent organization \\
\hline Team work & Openness & Business \\
\hline Troubleshooting & Creativity & Systems, products and \\
technology
\end{tabular}

Source: adapted from IPMA Brasil (2012).

The settings identified in the literature propose different skills for project professionals. We chose to use the skill set, as shown in Table 1, according to the IPMA Brasil (2012).

\subsection{Professional executive secretariat}

The Executive Secretariat has been a profession since 1985, regulated by Laws $7377 / 1985$ and $9261 / 1996$. To qualify, one must have higher education and training as a secretariat (Brasil, 1996). Since its origin, which is attributed to the scribes, the profession has undergone several changes. First, the Executive Secretariat served as an advisor and assistant to the executive. The Executive Secretariat demonstrated effective use of secretarial techniques, and always effectively and efficiently maximized and optimized technological resources. The profession now takes on more and more responsibilities as a result of the powers acquired within the upper reaches of the Executive Secretariat, which allows the professional to act to oversee the workings of entrepreneurs and consultants, with a focus on results (Vieira \& Zuin, 2015; Barros et al, 2013; Leal \& Moraes, 2017; Leal et al, 2020).

Assuming technical and behavioral skills, with a more flexible, resilient, and creative profile, ES no longer is a mere task executor (Martins et al., 2011). The technical and behavioral skills are presented in the Brazilian Curriculum Guidelines-DCN (Brasil, 2005), as shown in Table 2. The technical competence is based on knowledge gained in vocational training, is the deep knowledge of methods, processes and procedures of 
activities in the organization, and general know-how (Bernhardt, 2004). The behavioral competence is gained through experience, both professional and life. It is part of the set of social skills that are required to appropriately deal with situations of everyday life (Dias et al., 2014).

Table 2. Brazilian Curriculum Guidelines of ES.

\begin{tabular}{|c|c|}
\hline \multirow{11}{*}{$\begin{array}{l}\text { Technical } \\
\text { competences }\end{array}$} & $\begin{array}{l}\text { Articulation capacity according to the levels of the competences fixed by } \\
\text { organizations. }\end{array}$ \\
\hline & $\begin{array}{l}\text { General vision of the organization and peculiar hierarchical and inter-sector } \\
\text { relationships. }\end{array}$ \\
\hline & $\begin{array}{l}\text { Practice of management functions with solid mastery on planning, organization, } \\
\text { control and direction. }\end{array}$ \\
\hline & $\begin{array}{l}\text { Use of logical, critical, and analytical thinking, operating with values and } \\
\text { establishing formal and casual relationships between organizational } \\
\text { phenomena and situations. }\end{array}$ \\
\hline & Skills to deal with new models of management innovation. \\
\hline & $\begin{array}{l}\text { Domain of resources of expression and communication compatible with } \\
\text { professional practice, including in negotiation processes and in interpersonal } \\
\text { and intergroup communication. }\end{array}$ \\
\hline & $\begin{array}{l}\text { Effective use of secretary techniques, with new technologies allowing security, } \\
\text { credibility and loyalty in the flow of information. }\end{array}$ \\
\hline & $\begin{array}{l}\text { Adoption of alternative means related with improvement of quality and } \\
\text { productivity of services, identifying needs and providing solutions. }\end{array}$ \\
\hline & Information management, providing uniformity and references to different users. \\
\hline & Management and advisory aiming sectors and business objectives and goals. \\
\hline & Capability to the maximization and optimization of technical resources. \\
\hline \multirow{7}{*}{$\begin{array}{l}\text { Behavioral } \\
\text { Competences }\end{array}$} & Receptivity and leadership in team work, searching for synergy. \\
\hline & Initiative \\
\hline & Creativity \\
\hline & Determination \\
\hline & Willingness to learn \\
\hline & Openness to changes \\
\hline & Awareness for implications and ethical responsibility in the course of profession. \\
\hline
\end{tabular}

Source: adapted from Brasil (2005).

In addition to technical skills (writing texts, secretary meetings, organizing trips, events and institutional visits, and managing information), the ES should possess behavioral skills including interpersonal relations and ethics to deal with strategic and sensitive information. The ES position is "a key" within organizations due to its flexible profile and its multifunctional character (Neiva \& D'Elia, 2014; Moreira et al, 2016). Leal \& Moraes (2017) corroborating to highlight the multifunctional character and versatility of the ES, add the mainstreaming of knowledge, resoluteness, and innovativeness as new skills aggregated to the profession.

As facilitator, the ES has a special function in communication, facilitating the process of understanding and respect among colleagues. There are companies with successful experiences of ES groups involved in quality programs in order to optimize processes and work routines, cost reduction, and improvement of communication processes (Neiva \& D'Elia, 2014).

The ES is able to perform management activities such as monitoring and implementation of planning, participation in the distribution, supervision and control of 
employee activities, participation in the organization of working methods and processes involving the understanding of self and others, effective communication, team building, management of information through critical thinking, and coordination of projects and / or events (Barros et al., 2013).

The ES features a performance of diversity in the market, one of the idealization and development of implementation and execution of process improvement projects (Santos et al., 2013; Rodrigues \& Pradella, 2010). Corroborating this statement, Barros et al. (2013) emphasize the importance of ES to PM, working on the organizational challenges that are requested. The planning used constantly by ES contributes to better time management. Consequently, this professional can increase project teams' quality, by prioritization of activities schedules by urgency, and through provision of correct definitions. Their social and technical skills show the importance of ES's role with the project teams (Mota \& Magalhães, 2013).

By studying the ES's performance in projects, Piscopo \& Silveira (2013) revealed that the role and responsibilities of this professional should be set initially. ES who are inserted into complex projects provide support to managers and project teams, and contribute to a positive result, especially in the information flow and communication of projects studied. This is especially found for interpersonal skills and access to different functional areas, and the only need is to deepen their knowledge of PM.

In a survey conducted by Todorov et al. (2013a) on the powers of secretarial professionals in the implementation of sustainable projects, it was found that the ES is involved in the management of these projects. Of the 206 respondents, $26 \%$ are directly involved in the implementation and execution, $20 \%$ in the advice to the project team, and $5 \%$ are involved in managing the communications area.

The ES is prepared to take on new responsibilities in the face of changing their profile and their new technical and behavioral skills, but some companies did not follow this trend and delegated only operational tasks to the ES, not using them to their full potential to benefit the processes in the organization (Neiva \& D'Elia, 2014; Halice et al., 2012). Therefore, the managers' knowledge of the competences of the professional Secretariat benefits processes, such as PM.

In this context, we present the first hypothesis related search:

$\mathrm{H} 1$ - Knowledge of project manager of the ES expertise benefits the PM processes.

$\mathrm{H} 2$ - Knowledge of project manager of the ES behavioral skills benefits the PM processes.

Communication difficulties rank among the top reasons that hinder projects (Lu et al, 2014). Among the ES skills are interpersonal or inter-group communications (Brasil, 2005), which are also among the technical skills of the project team. It is for the ES to take on more responsibility, consistent with their knowledge, with the exercise of leadership, among others (Vieira \& Zuin, 2015). Faced with this problem the following hypotheses were tested:

H3 - The ES uses the technical and contextual skills of the project team.

H4 - The ES uses the behavioral skills of the project team.

There are several ES skills that relate to the competence of the project team. In order to relate the ES skills to the professional skills needed for the projects, according to the project manager's perspective, we chose to use the ES skills as outlined by Brasil (2005). In this way, we can compare the technical and behavioral skills of the ES with the skills of the project team.

Thereby:

H5 - The project manager realizes the ES contributes to the PM, due to the ES skills. 
$\mathrm{H} 6$ - The project manager realizes the ES contributes to the PM, due to the project team skills.

Figure 1 shows the theoretical model developed from the literature review.

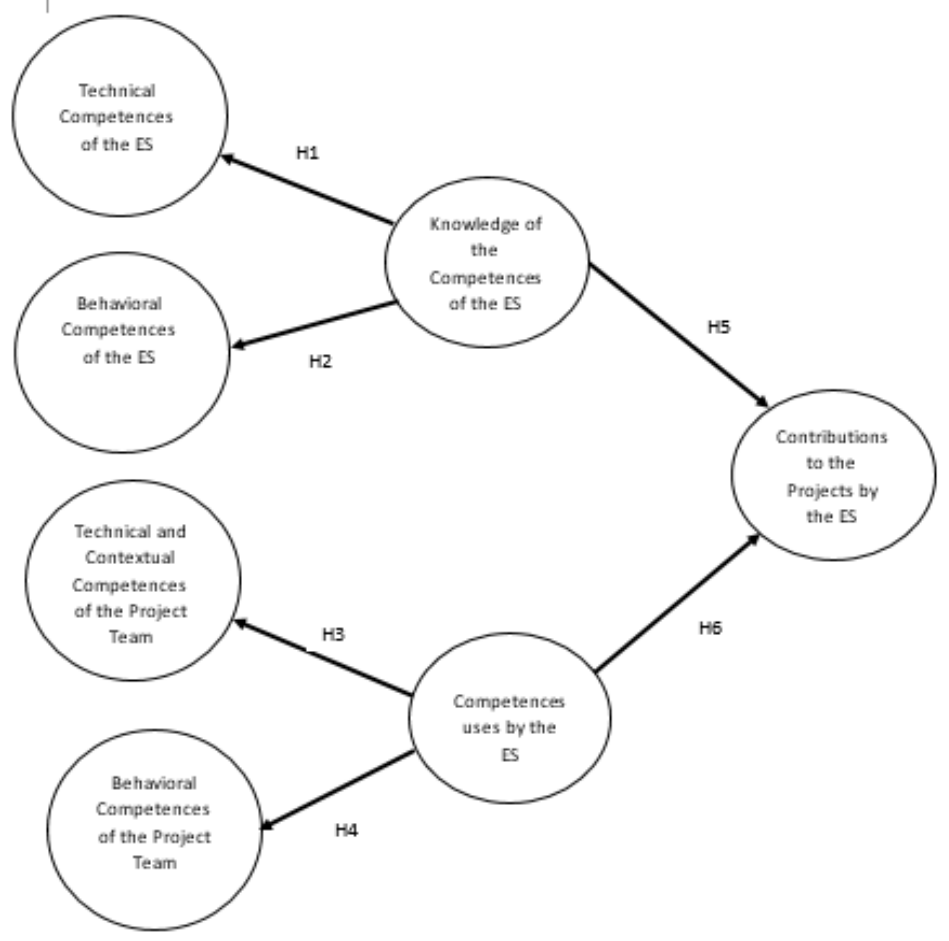

Figure 1. Theoretical Model.

\section{Research methodology}

This chapter presents the research methodology, describing the nature of the study, methods, techniques, and constructs analyzed during the empirical phase of this study.

The empirical phase of this study can be categorized as a descriptive and quantitative (Hair et al., 2016), and was conducted through a survey (Cooper \& Schindler, 2013). Data were analyzed using structural equation modeling (SEM), using the correlation matrix and partial least squares (PLS-PM - partial least square - path modeling) (Ringle et al., 2014) and also using SEM. The analysis verified the perception of project managers regarding the contribution of ES in PM.

The sample selection did not follow probabilistic criteria for convenience (Hair et al., 2016). For definition of the population, the entity was selected representing the secretariat of professionals in São Paulo, the Union of Secretaries of the State of São Paulo (SINSESP). The scope of the research included 4,000 project managers linked with SINSESP associates.

Non-probabilistic studies that use structural equation modeling, see Malhotra et al. (2014), recommend that each construct be measured by at least three observed variables. Attending to this assumption, the present study, which contains five constructs, used at least seven variables for measurement. However, to ensure an adequate sample size, we used the $G$ * Power 3.1 .9 software which indicates that for a power of .80 and a median effect size (.15), the minimum sample size of 68 subjects (Ringle, Silva, \& Bido, 2014). 
The constructs of the research were aligned with the references used, taking into account the purpose of the study. In Appendix A, the constructs of the research are presented with their theoretical and operational definitions, also pointing to the source associated with each construct, in addition to the variables used in the questionnaire.

The construction of the data collection instrument began by analyzing the skill concepts for the ES and for project professionals. Based on the theoretical framework, a list of variables was created. The choice of the skills of the Secretariat was based on the Curriculum Guidelines Course (Brasil, 2005), as variables for this research are justified because they are officers of the National Council of Education. The skills of the project professional, were based on IPMA Brasil (2012), and are justified by the number of variables that contribute to a better result, but also to present technical and behavioral skills, just as the skills presented in the Curriculum Guidelines of the professional secretariat course.

In the initial analysis of empirical data we verified the normality (KS KolmogorovSmirnov test), the absence of outliers, uni (box-plot chart) and multivariate ( $D^{2}$ Mahalanobis), the absence of multicollinearity (inflation factor variance - VIF) and homoscedasticity of the distribution (Levene's test), using SPSS.

For structural equation modeling, we conducted an analysis of the correlation matrix, using the SmartPLS 2.0M3 software.

\section{Results}

A driven pretest with four respondents indicated the necessary adjustments to the elaboration of the final version of the data collection form.

The survey questionnaire was sent to 4,000 people via the internet. The research was viewed by 444 people ( $11.1 \%$ of mailing). Only 249 respondents $(56.1 \%$ of respondents and $6.2 \%$ of accessed) started the questionnaire, but 175 did not answer all questions. For this reason, these were excluded from the database. The final sample was composed of 75 completed and valid questionnaires, answered by project managers ( $16.9 \%$ of respondents and $1.9 \%$ of accessed).

The proportion of female responders $(76 \%)$ was higher than that of male responders $(24 \%)$ and in relation to age, $9.34 \%(n=7)$ of respondents were under $30,29.3 \%(n=22)$ were between 31 and 39 years, 36\% $(n=27)$ were between 40 to 49 years, 20\% $(n=15)$ were between 50 and 59 years, and $5.3 \%(n=4)$ were over 60 years.

With regard to the education of the respondents, $53.16 \%(n=40)$ have graduate degrees, $94.7 \%(n=71)$ have higher education, 31\% $(n=22)$ in Administration and $4 \%$ $(n=3)$ at the technical level. Among the respondents, $54.7 \%(n=41)$ have been working for more than 10 years as project managers and coordinate 13 people on average.

The results showed that $17.03 \%(n=13)$ of organizations have fewer than 10 employees, $10.07 \%(n=8)$ have up to 49 employees, $12 \%(n=9)$ up to 99 employees and $60 \%(n=45)$ over 100 employees. The companies' lines of business were quite heterogeneous, however, most were concentrated in the service sector $(13.69 \%)$, with $69.30 \%(n=62)$ being private, $20 \%(n=15)$ public, $6.70 \%(n=5)$ mixed, and $4 \%(n=3)$ from the third sector. Respondents were concentrated in São Paulo (96.10\%).

Apart from performing project management functions, to be considered for this study, the participants were also required to have participated with an ES on a project team, at some time in the last twelve months. Of the respondents, $57.3 \%(n=43)$ had worked with an ES at the time of participation in the research while the other $46.7 \%(n=32)$ had managed an ES last year. 
Analysis of the Box-plot chart did not indicate the existence of a univariate outlier, and the Mahalanobis distance $\left(D^{2}\right)$ was not significant for any data $\left(x^{2}=n . s\right.$.) (Hair et al., 2016).

Similarly, the absence of Multicollinearity was identified by analyzing the inflation factor of less variance than 10 for all manifest variables (biggest value of the VIF $=4.76$ CC_SE_6 variable). Even if there is a critical limit for the test, there is the understanding that VIFs below 10 indicate no multicollinearity (Hair et al., 2016). Also as expected, the Levene's test revealed no traces of sample heteroscedasticity $(p<.01)$.

Finally, there was examination of normal distribution of the data of the dependent variables in the model. The KS test - Kolgomorov Smirnov, alternative to W Shapiro-Wilk for larger samples to 20 subjects, indicated the absence of normality in the data. This result reinforces the decision to use the estimation by correlation matrix, using the SmartPLS for the analysis of the structural model.

\subsection{Structural equation modeling}

In this section we present the results observed in the analysis of the structural model.

Initially, as recommended in the literature (Ringle et al., 2014), we proceeded to the verification of convergent and discriminant validity of the model.

\subsubsection{Convergent Validity}

Convergent validity is obtained by observations of the loads between the manifest variables and the constructs to which these relate. As indicated by Ringle et al. (2014), loads of more than .50 indicate good adjustment and power formative contribution to the latent variable.

As shown in Figure 2, loads range from .583 to .961 . Thus, by this criterion, it was not necessary to eliminate any observed variable.

\subsubsection{Discriminant Validity}

In checking the discriminant validity we used the criterion of Fornel and Larcker. By that standard, widely used in structural equation modeling, we obtain the discriminant validity when the square root of the AVE (average variance extracted) of the construct is greater than the correlation of this with the other constructs of the model analyzed (Ringle et al. 2014; Hair et al., 2016).

As shown in Table 3, the model meets the Fornel and Larcker's criteria without any required adjustment.

Table 3. Discriminant Validity of the Model.

\begin{tabular}{cccccccc}
\hline & AVE & AVE Root & $\mathbf{1}$ & $\mathbf{2}$ & $\mathbf{3}$ & $\mathbf{4}$ & $\mathbf{5}$ \\
\hline (1) Compet_Beh_PT & .826 & .909 & .909 & & & & \\
\hline (2) Compet_Technic_PT & .641 & .801 & .873 & .801 & & & \\
\hline (3) Compet_Technic_ES & .705 & .839 & .666 & .709 & .839 & & \\
\hline (4) Compet_Beh_ES & .757 & .870 & .727 & .613 & .753 & .870 & \\
\hline (5) Contribution ES & .670 & .818 & .839 & .775 & .670 & .684 & .818 \\
\hline
\end{tabular}

The highlighted diagonal presents the AVE square root of the construct. The other cells indicate the correlation between them. 


\subsection{Adequacy Indicators of the Model}

The next step was to observe the values of internal consistency by Cronbach's alpha $(A C)$, Composite Reliability (CC), the determination coefficients $\left(R^{2}\right)$ and Communality.

Even if the $A C$ is sensitive to the number of variables in each construct and the $C C$ is affected by the covariance between items (Hair et al., 2016), we use the AC and DC to see if the answers are reliable (Ringle et al, 2014). The results are shown in Table 4.

Table 4. Indicators of adequacy of the structured model.

\begin{tabular}{cccccc}
\hline & AVE & $\begin{array}{c}\text { Composite } \\
\text { Reliability }\end{array}$ & $\begin{array}{c}\text { Cronbach's } \\
\text { Alpha }\end{array}$ & $\mathbf{R}^{2}$ & Communality \\
\hline Compet_Beh_PT & .826 & .981 & .979 & .935 & .826 \\
\hline Compet_Technic_PT & .641 & .964 & .960 & .938 & .641 \\
\hline Compet_Tecnicas_ES & .705 & .963 & .958 & .918 & .705 \\
\hline Compet_Beh_ES & .757 & .956 & .946 & .827 & .757 \\
\hline Knowledge ES & .638 & .969 & .966 & & .638 \\
\hline Contribution ES & .670 & .941 & .927 & .717 & .670 \\
\hline Uses_Compet_ES & .674 & .982 & .980 & & .674 \\
\hline
\end{tabular}

Critical limits according to Ringle et al. (2014) - AC e CC >.70, AVE and Communality >.50.

Given these results, we started the analysis of structural relations.

\subsection{Evaluation of path model}

The structural model or model paths explains the portion of the variation of dependent variable(s) explained by independent variable(s) of the analysis model (Hair et al., 2016). This explanation power is indicated by a coefficient of determination $\left(R^{2}\right)$ that can vary between 0 and 1 . Because it is a percentage of the variation, an $R^{2}$ of .49 indicates that $49 \%$ of the dependent variable is explained by the independent variable(s).

As shown in Figure 2, 71.7\% of ES's contribution to the project management perceived by managers is explained by variables ES Knowledge and Use of ES Skills. Notably, Use of ES Skills has a much greater weight $(\beta=0,670)$ in the explanation of the dependent variable when comparing the importance of ES knowledge, perceived by the manager $(\beta=.219)$.

\subsubsection{Coefficients of Assessment and Significance Test}

The coefficients of determination of Pearson $\left(R^{2}\right)$ are large, as shown in Table 3, and the loads of the constructs were positive, but some factor loadings showed low levels (for details see Cohen et al., 2013).

\subsubsection{Testing Hypotheses}

To check the significance of relationships, we used the resampling bootstrapping test with 200 repetitions. To evaluate whether the relationships were significant, we calculated a Student's t test among the original data values and those obtained by the resampling bootstrapping technique, where the original data was repeatedly sampled by extracting a large number of sub-samples and pricing models for each one presenting the best 
coefficients and the expected variability (Hair et al., 2016; Ringle et al., 2014). As Table 5 shows, all values are higher than the amount indicated as recommended and appropriate.

Only the path of the contribution of ES in projects with the construct technical and behavioral competences which tested H5 (The project manager realizes the SE contribution to the PM, due to the ES skills) presented $t(199)=.959$; with $p>.01$, thus considered not significant.

Table 5. Test of the Hypothesis

\begin{tabular}{|c|c|c|c|c|c|c|c|}
\hline Hypothesis & $\begin{array}{l}\text { Expected } \\
\text { relationship }\end{array}$ & Path & $\begin{array}{l}\text { Original } \\
\text { load }\end{array}$ & $\begin{array}{c}\text { Means of } \\
\text { the } \\
\text { resampling } \\
\text { bootstraping }\end{array}$ & $\begin{array}{l}\text { Standart } \\
\text { error }\end{array}$ & Test $\mathbf{t}$ & Sig. \\
\hline H1 & + & $\begin{array}{l}\text { Knowledge of ES -> } \\
\text { Compet_Technic_ES }\end{array}$ & .958 & .957 & .013 & 75.964 & $p<.01$ \\
\hline $\mathrm{H} 2$ & + & $\begin{array}{l}\text { Knowledge of ES -> } \\
\text { Compet_comp_ES }\end{array}$ & .910 & .902 & .043 & 21.113 & $p<.01$ \\
\hline H3 & + & $\begin{array}{l}\text { Use_Compet_ES -> } \\
\text { Compet_Technic_PT }\end{array}$ & .969 & .967 & .015 & 66.162 & $p<.01$ \\
\hline H4 & + & $\begin{array}{c}\text { Use_Compet_ES -> } \\
\text { Compet_Beh_PT }\end{array}$ & .967 & .966 & .012 & 8.453 & $p<0,01$ \\
\hline H5 & + & $\begin{array}{c}\text { Knowledge of ES -> } \\
\text { Contribution ES }\end{array}$ & .219 & .308 & .229 & .959 & N.S. \\
\hline $\mathrm{H} 6$ & + & $\begin{array}{c}\text { Use_Compet_ES -> } \\
\text { Contribution ES }\end{array}$ & .670 & .580 & .238 & 2.817 & $p<.01$ \\
\hline
\end{tabular}

Critical limits for $\mathrm{t}_{(199):} 1.96=\mathrm{p}<.05$ e $2.53=\mathrm{p}<.01$

Note: "N.S." = non-significant - Hypothesis not supported by the empirical data

Figure 2 shows the structural theoretical model, with the respective coefficients. The amount shown within the construct (circle) shows how this variable is explained by the other constructs. The numbered variables in rectangles are detailed in Appendix A.

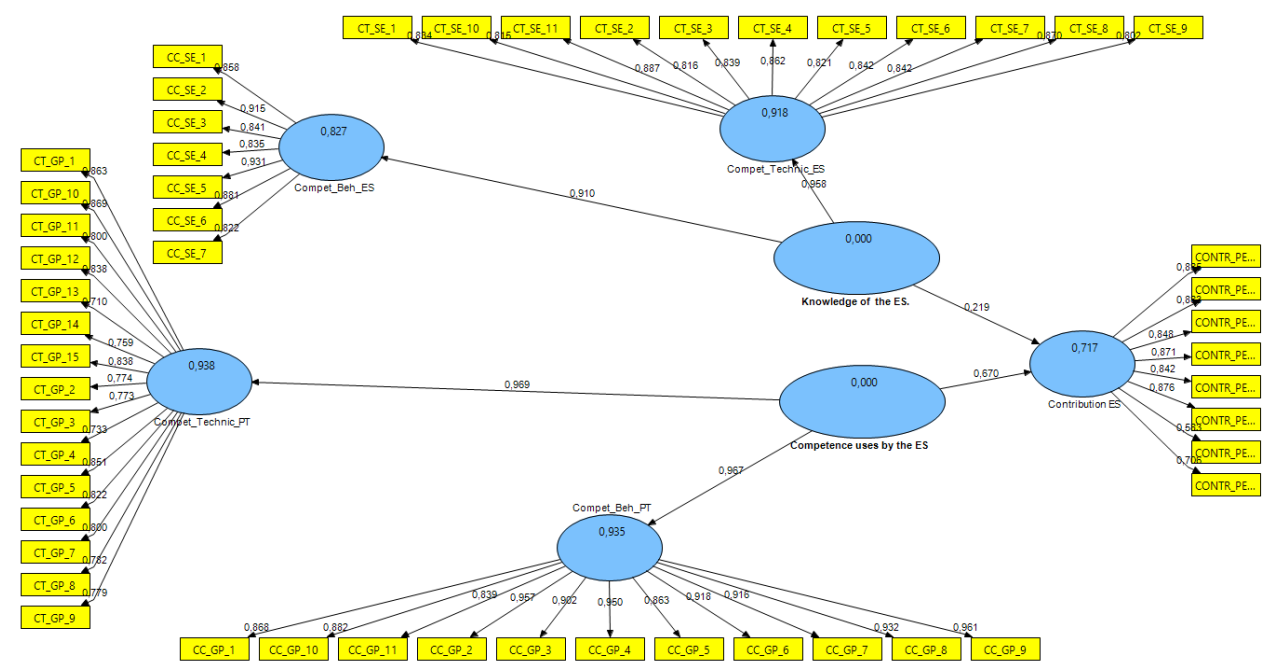

Figura 2. Structural Model. 


\subsection{Discussion of results}

This study analyzed the perceptions of project managers regarding the ES contribution to PM, using five constructs measuring ES skills and those of the project team. The relationships between the constructs involved in the research were represented by the use of paths and indicated good condition to be processed and analyzed by SmartPLS2.0M3 software for multivariate analysis. This allowed for the testing of each of our hypotheses to answer the research problem.

The relationship between the knowledge of project managers and the skills ES constructs showed consistent results. The same happened between the use by the ES and the relationship with the constructs of project team skills, as shown below.

Verifying the relationship between the constructs technical competences of the ES and the competences of the project team, project managers believe that the ES can facilitate the connection between the team members and contribute to the smooth implementation of the entire PM. A general view of the organization enables the ES to take a broad view of everything that happens within the scenario to understand the problems more quickly and efficiently and to identify possible solutions. This general view also enables the ES to work on different types of projects, favoring the strategic execution of organizations. The field of expression and communication resources by ES helps in reducing communication failures, increasing the possibility of an effective exchange among members, and a better understanding of information between the parties (Leal \& Fiates, 2013; Bernhardt, 2004; Moreira et al, 2020).

The project manager showed lack of certainty for the ES's use of management functions and the use of logical, critical, and analytical reasoning, which can demonstrate that the ES has not mastered this skill as needed. Therefore, the development of managerial skills is part of the new approach that the ES has taken in recent years. Also the project manager showed a similar lack of certainty in the adoption of alternative media related to improving the quality and productivity of services, which was surprising as there are already ES groups involved in quality programs, optimizing processes and work routines, generating improved communication and reducing costs (Neiva \& D'Elia, 2014; Todorov et al, 2013b; Moreira et al, 2016). To reverse this result ES can search for existing groups to become familiar with the processes adopted and apply them to their project teams.

In the construct of behavioral skills of the ES and the project team, the skills were positively perceived by project managers. The project manager demonstrated knowledge that the ES has a positive outcome on competence responsiveness and leadership and improves the team's performance (Araújo \& Pedron, 2015; Moura et al., 2019; Bennet, 2017). The ES initiative profile decreases the time needed to solve problems. Creativity of the ES also contributes to solving problems, because in many situations the ES needs to be creative to see a problem or create an opportunity (Neiva \& D'Elia, 2014; Vieira \& Zuin, 2015). Furthermore, the interest in learning within a project team can generate new knowledge, and form critical and motivated team members, which according to Steenkamp (2014) also contributes to effective communication. Openness to change and competence were also validated by project managers. When the need for change emerges in a project, in relation to the scope, cost, or schedule, for example, those professionals open to changes may have better results and adapt better to new groups, if necessary (Araújo \& Pedron, 2015; Almeida \& Ramos Filho, 2018).

With respect to contextual skills of the project team, the results showed that the ES has yet to become better acquainted with these skills, corroborating the literature (Piscopo \& Silveira, 2013). On the one hand, the general view of the ES, not being specialists in 
PM, were not expected to be perceived as having these skills. On the other hand, as a member of the project team, the ES needs to better develop these skills for a greater contribution as a team member. Surprisingly, project managers showed a positive result regarding the use of permanent organization by the ES. It is possible to believe that this occurrence is due to the fact that to use that power you need to know and relate to all levels of the organization and as pointed out in the literature review, this is part of the ES profile (Halice et al., 2012; Neiva \& D'Elia, 2014).

The certainty of project managers about the effectiveness of the contribution of the ES in project communication corroborates the literature that demonstrated the important role of this professional for successful communication within the project. With these results we can say that is mainly on improving communication that project managers can count on the ES, both in communication between staff, as communication with management, and stakeholders, building a cohesive communication that will favor the performance of the projects (Oliveira et al., 2018).

The benefit of PM processes through the analysis of knowledge of project managers on the construct technical competence of the ES, was tested by $\mathrm{H} 1$ and showed a good knowledge on the part of managers, benefiting PM processes. The reviewed literature had shown that businesses, in general, did not follow the evolution of the ES, delegating operational tasks only and not taking advantage of their potential (Neiva \& D'Elia, 2014; Halice et al, 2012; Bernardino \& Nunes, 2014; Barbosa \& Durante, 2013; Bernardino \& Nunes, 2014), which would mitigate the extent of their performance.

The behavioral competences, which are acquired through professional and personal experience (Brière, Proulx, Flores, \& Laporte, 2015) corresponded to and supported H2. Receptivity to teamwork and leadership in the pursuit of synergy, initiative, creativity, determination, desire to learn, openness to change, awareness of the implications, and ethics of their professional practice responsibilities are skills that most respondents attribute to the ES.

The use of the constructs related to technical contextual competences of the project team by the ES was tested in $\mathrm{H} 3$ and was also validated. The skills that had a higher result when the ES project manager performs them were: teamwork, communication on multiple levels; problem solving and people management. These skills are presented in the literature as deficient in project team, which can compromise the success of projects (Rabechini et al., 2011, IPMA Brasil, 2012).

Behavioral skills used by the ES were tested by hypothesis $\mathrm{H} 4$ and validated. Leadership, commitment and motivation, self control, assertiveness, creativity, results orientation, efficiency, and ethics are skills positively associated with the ES. Also, casualness, openness, and negotiation are skills that deserve special attention from the $\mathrm{SE}$, so that project managers have assured that the ES develops.

The perception of the project manager on the contribution of the ES, taking into account the knowledge of ES skills, was tested for $\mathrm{H} 5$ and there is no theoretical support, according to the evidence presented, to believe that knowledge of ES skills, by the project managers, who already have a ES in the team, hinder the contribution of these professionals within the project team, so $\mathrm{H} 5$ was rejected.

The confirmation of $\mathrm{H} 6$ attests that project managers realize the ES contributes to the PM, due to the project team skills. In this case, taking into account that many of the ES's skills relate to the skills of the project team, the rejection of $\mathrm{H} 5$ does not harm the proposed model of assessing the ES's contribution. We can say that the proposed theoretical model is robust. The relationships proposed in the model demonstrate the ES's contribution within the project team. 
As a result of this study, we found that the ES's skills are adherent to the PM team, contributing to effective project management. With this result, we found that project managers can get ES support to achieve project success.

As an academic contribution, this study set out to investigate the perception of ES competencies within the PM team because there have been limited theoretical and empirical studies with this approach. For organizations, it is relevant for allowing better results in $\mathrm{PM}$.

\section{Final thoughts}

The results found among respondents who have an ES on their team that managers are aware of most ES skills and indicate that knowledge of ES competences by the project managers can make a difference in the inclusion of an ES on the team. It is also necessary that the ES strives to show the managers skills such as: i) exercise of management functions, since these professionals have a solid grip on planning, organization, control and direction; and ii) ability to deal with innovative management models and capacity maximization and optimization of technological resources, as these skills are not known to all respondents.

We identified the following activities carried out by ES in PM, according to the perception of the project manager: teamwork, communication on multiple levels, problem solving, and people management. Corroborating the literature, communication is a strong competence of the ES (Piscopo \& Silveira, 2013), and at the same time is one of the most cited reasons for failure in PM (Kerzner, 2017; Vezzoni et al., 2013). The activities related to the technical and contextual skills, although also identified as performed by the ES, showed a need to be better developed by the ES.

The study made it possible to confirm that the project manager realizes the ES contribution to the PM due to the ES's relation with the competences of the project team.

After meeting the proposed objectives, this study allowed us to highlight the importance of the ES for the PM. Knowledge of the ES skills by project managers verifies that ES use the project team's competences as members themselves, thus answering the research question. The results reinforced the belief of lack of synergy between the ES and the project manager may be due to the small number of respondents who have not yet integrated the ES on their project team.

Due to lack of work by ES and the project team, it was expected that the return of respondents would be a limitation. However, with the completion of this study, it is believed that the number of secretaries involved in the project team will increase in the long run, which will benefit other research on the subject. For future work, it is suggested to carry out a survey to compare the success of projects using teams who utilize an ES to those without an ES. Moreover, the search may also be reapplied to a higher number of respondents.

\section{Acknowledgements}

The author Cláudia Kniess thanks the support of the National Council for Scientific and Technological Development (CNPq) for the Productivity Scholarship in Technological Development and Innovative Extension. 


\section{References}

Almeida, H. R., \& Ramos, A. C. Fo (2018). Conceitos da gestão de mudanças organizacionais aplicados ao gerenciamento de projetos: Utilização do HCMBOK em um Projeto de Engenharia. Revista IPTEC, 6(2), 59-71. http://dx.doi.org/10.5585/iptec.v6i2.148.

Amaral, A., Fernandes, G., \& Varajão, J. (2015). Identifying useful actions to improve team resilience in information systems projects. Procedia Computer Science, 64, 1182-1189. http://dx.doi.org/10.1016/j.procs.2015.08.549.

Araújo, C. C. S., \& Pedron, C. D. (2015). The IT project manager competencies that impact project success-A qualitative research. Organisational Project Management, 2(1), 53-75. http://dx.doi.org/10.5130/opm.v2i1.4142.

Barbosa, S. M. C., \& Durante, D. G. (2013). Secretariado executivo e empreendedorismo: Realidade ou Utopia? Revista de Gestão e Secretariado, 4(1), 56-74. http://dx.doi.org/10.7769/gesec.v4i1.143.

Barros, C. D. M. P., Silva, J. S., Lima, G. A., \& Brito, D. G. S. (2013). As competências gerenciais desenvolvidas pelos secretários executivos. Revista de Gestão e Secretariado, 4(2), 25-47. http://dx.doi.org/10.7769/gesec.v4i2.131.

Bennet, N. (2017). Managing Successful Projects with PRINCE2. Norwich: The Stationery Office.

Bernardino, W. M., \& Nunes, W. S. (2014). Responsabilidade Social: O Secretário Executivo como agente facilitador de Estratégias no Ambiente Corporativo. Revista Expectativa, 13(13), 29-48.

Bernhardt, D. (2004). Competitive intelligence: how to acquire and use corporate intelligence and counter-intelligence. London: Prentice Hall.

Bíscoli, F. R. V., \& Bilert, V. S. S. (2013). A evolução do secretariado executivo: caminhos prováveis a partir dos avanços da pesquisa científica e dos embates teóricos e conceituais na área. Revista Expectativa, 12(12), 9-42.

Brasil. (1996, 10 de janeiro). Lei $n^{\circ}$. 9261, de 10 de janeiro de 1996. Dispõe sobre o exercício da profissão de Secretário e dá outras providências. Brasília: Diário Oficial da República Federativa da União. Recuperado em 22 de novembro de 2017, de http://www.planalto.gov.br/ccivil_03/leis/L9261.htm

Brasil. Conselho Nacional de Educação. Câmara de Educação Superior. (2005, 14 de julho). Resolução CNE/CES n ${ }^{\circ}$ 4, de 23 de junho de 2005. Institui as Diretrizes Curriculares Nacionais do curso de graduação em Secretariado Executivo (Seção 1, p. 79). Brasília: Diário Oficial da República Federativa da União. Recuperado em 22 de novembro de 2017, de http://portal.mec.gov.br/cne/arquivos/pdf/rces003_05.pdf

Brière, S., Proulx, D., Flores, O. N., \& Laporte, M. (2015). Competencies of project managers in international NGOs: perceptions of practitioners. International Journal of Project Management, 33(1), 116-125. http://dx.doi.org/10.1016/j.ijproman.2014.04.010.

Carvalho, D. S. S., Barreto, L. K. S., Brito, L. M. P., \& Rocha, M. P. No. (2019). A gestão do conhecimento na percepção dos secretários executivos de uma instituição federal de ensino. Revista de Gestão e Secretariado, 10(2), 1-29. http://dx.doi.org/10.7769/gesec.v10i2.826.

Carvalho, M. M., \& Rabechini, R. Jr (2011). Fundamentos em gestão de projetos - Construindo competências para gerenciar projetos. São Paulo: Atlas.

Cohen, J., Cohen, P., West, S. G., \& Aiken, L. S. (2013). Applied multiple regression/correlation analysis for the behavioral sciences. New York: Routledge. http://dx.doi.org/10.4324/9780203774441.

Cooper, D., \& Schindler, P. (2013). Business research methods (12th ed.). New York: McGraw-Hill Global Education.

Dias, C. M. Jr, Morei, B. C. M., Stosick, E. Z., \& Pereira, A. R. (2014). Desenvolvimento de competências do administrador: um estudo em ambiente simulado. Revista de Ciências da Administração, 16(38), 172-182. http://dx.doi.org/10.5007/2175-8077.2014v16n38p172. 
Fleury, M.T.L., \& Fleury, A. (2001). Construindo o conceito de competência. Revista Administração Contemporânea, 5(spe), 183-196. http://dx.doi.org/10.1590/S1415-65552001000500010.

Hair, J. F. Jr, Hult, G. T. M., Ringle, C., \& Sarstedt, M. (2016). A primer on partial least squares structural equation modeling (PLS-SEM). Thousand Oaks: Sage Publications.

Halice, A., Yilmaz, B., \& Kasimoğlu, M. (2012). Employment Preedictions in Secretarial Occupation. Journal of Management and Sustainability, 2(2), 187-196. http://dx.doi.org/10.1016/j.sbspro.2011.09.119.

Hamel, G., \& Prahalad, C. K. (2013). Competing for the Future. Boston, Massachusetts: Harvard Business Press.

IPMA Brasil. (2012). National Competence Baseline 3.0. Rio de Janeiro: IPMA Brasil.

Kerzner, H. (2017). Project management: a systems approach to planning, scheduling, and controlling. Berea, Ohio: John Wiley \& Sons.

Leal, F. G., \& Fiates, G. G. S. (2013). Competências dos secretários-executivos de uma universidade pública federal: uma análise a partir da perspectiva dos gestores. Revista de Gestão e Secretariado, 4(3), 30-57. http://dx.doi.org/10.7769/gesec.v4i3.216.

Leal, F. G., \& Moraes, M. C. B. (2017). Perspectivas de atuação do secretário executivo na gestão da internacionalização da educação superior. Revista de Gestão e Secretariado, 8(1), 138167. http://dx.doi.org/10.7769/gesec.v8i1.575.

Leal, F., Paes, R. O., \& Moraes, M. C. B. (2020). O secretário-executivo na gestão da internacionalização da educação superior brasileira. Série-Estudos, 25, 153-174.

Lin, T. C., Chen, C. M., Hsu, J. S. C., \& Fu, T. W. (2015). The impact of team knowledge on problem solving competence in information systems development team. International Journal of Project Management, 33(8), 1692-1703. http://dx.doi.org/10.1016/j.ijproman.2015.07.007.

Lu, Y., Luo, L., Wang, H., Le, Y., \& Shi, Q. (2014). Measurement model of project complexity for large-scale projects from task and organization perspective. International Journal of Project Management. http://dx.doi.org/10.1016/j.jproman.2014.12.005.

Magalhães, L., Figueiredo, L. B., \& Jesus, L. T. D. (2020). Project management in public-private partnerships: a conceptual framework based on a systematic literature review. Gestão \& Produção, 27(1), e3772. http://dx.doi.org/10.1590/0104-530x3772-20.

Malhotra, N. K., Lopes, E. L., Veiga, R. T. (2014). Structural Equation Modeling with Lisrel: An initial vision. Revista Brasileira de Marketing - Remark, 13(2), 28-43.

Martins, C. B., Genghini, A. L., \& Todorov, M. C. A. (2011). A resiliência na atuação profissional em secretariado. Secretariado Executivo em Revist, 7, 9-20. http://dx.doi.org/10.5335/ser.v7i0.2323.

Moreira, K. D., Rodrigues, L. M. A., Dalmau, M. B. L., \& Costa, A. M. (2020). Metodologia para o desenvolvimento de competências secretariais no contexto da gestão universitária. Revista de Gestão e Secretariado, 11(1), 151-175. http://dx.doi.org/10.7769/gesec.v11i1.1043.

Moreira, K. D., Rodrigues, L. M. A., do Vale, J. C. F., \& Rosa, M. H. (2016). As competências contemporâneas do Secretário Executivo e a relação com as competências do Middle Manager. Revista de Gestão e Secretariado, 7(1), 45-66. http://dx.doi.org/10.7769/gesec.v7i1.400.

Mota, A., \& Magalhães, V. (2013). A equipe de projetos e a atuação do profissional em secretariado. In M. E. S. D’Elia, M. Amorim, \& M. Sita (Orgs.), Excelência no secretariado (pp. 343-349). São Paulo: Ser Mais.

Moura, I., Dominguez, C., \& Varajão, J. (2019). Information systems project teams: factors for high performance. Team Performance Management, 25(1/2), 69-83. http://dx.doi.org/10.1108/TPM03-2018-0022.

Moura, R. L. D., Carneiro, T. C. J., \& Diniz, B. D. (2018). Influência das características pessoais do gerente de projetos no desempenho dos projetos. Gestão \& Produção, 25(4), 751-763.

http://dx.doi.org/10.1590/0104-530x3595-16. 
Neiva, E. G., \& D'Elia, M. E. (2014). As novas competências do profissional de secretariado (3. ed.). São Paulo: IOB.

Oliveira, R. R., Cruz, J. E., \& Oliveira, R. R. (2018). Fatores críticos de sucesso na gestão de projetos: Análise dos indicadores que constituem os predecessores da estratégia, pessoas e operações. Revista de Gestão e Projetos, 9(3), 49-66.

Paes, R. V. O., \& Santiago, C. S. (2020). Assessoramento remoto por meio de escritórios virtuais: uma categorização de serviços prestados. Revista de Gestão e Secretariado, 11(1), 41-62. http://dx.doi.org/10.7769/gesec.v11i1.1055.

Piscopo, M. R., \& Silveira, F. F. (2013). The role of the administrative professional in the management of complex projects. Revista de Gestão e Secretariado, 4(3), 210-228. http://dx.doi.org/10.7769/gesec.v4i3.270.

Project Management Institute, Inc. (2017) A Guide to the Project Management Body of Knowledge - PMBOK(r). Guide (6th ed.). Newtown Square, PA: Project Management Institute, Inc.

Rabechini, R. Jr, Carvalho, M. M., Rodrigues, I., \& Sbragia, R. (2011). A organização da atividade de gerenciamento de projetos: os nexos com competências e estrutura. Revista Gestão \& Produção, 18(2), 409-424. http://dx.doi.org/10.1590/S0104-530X2011000200014.

Ringle, C. M., Silva, D. D., \& Bido, D. (2014). Structural Equation Modeling with the Smartpls. REMark: Revista Brasileira de Marketing, 13(2), 56-73. http://dx.doi.org/10.5585/remark.v13i2.2717.

Rodrigues, L. C., \& Pradella, S. (2010). O Profissional de Secretariado alavancando a Gestão por Processos. In: XVII Congresso Nacional de Secretariado. Fortaleza: XVII CONSEC Congresso Nacional de Secretariado.

Santos, G. T., Schuster, M. M., \& Pradella, S. (2013). Gestão da qualidade versus gestão por processos: metodologias unidas para dar maior competividade à indústria. Secretariado Executivo em Revista, 9, 51-64.

Shenhar, A., \& Dvir, D. (2010). Reinventando gerenciamento de projetos: a abordagem diamante ao crescimento e inovação bem-sucedidos. São Paulo: M. Books do Brasil.

Snoeijer, E., Moreira, K. D., \& Martins, C. B. (2019). A gestão do conhecimento e a atuação do secretário executivo no processo transitório da coordenação de um programa de pósgraduação. Revista de Gestão e Secretariado, 10(3), 1-26. http://dx.doi.org/10.7769/gesec.v10i3.1029.

Souza, A. P., Maier, C., \& Maçaneiro, M. B. (2013). Diagnóstico da Gestão do Conhecimento nas Atividades Secretariais. Revista Expectativa, 7(12), 77-100.

Steenkamp, D. H. (2014). Project teams: The relationship between motivation and communication as experienced by it and business members (Doctoral dissertation). Capella University.

Takey, S. M., \& Carvalho, M. M. (2015). Competency mapping in project management: an action research study in an engineering company. International Journal of Project Management, 33(4), 784-796. http://dx.doi.org/10.1016/j.ijproman.2014.10.013.

Thamhain, H. J. (1993). Team building in project management. In D.I. Cleland \& W.R. King. Project Management Handbook. New York: Van Nostrand Reinhold.

Thamhain, H. J. (2012). The changing role of team leadership in multinational project environments. Revista de Gestão e Projetos - GeP, 3(2), 4-38. http://dx.doi.org/10.5585/gep.v3i2.110.

Todorov, M. C. A., Kniess, C. T., \& Chaves, M. S. (2013b). As competências do profissional de secretariado na implantação de projetos sustentáveis. Revista de Gestão e Secretariado, 4(3), 189-209. http://dx.doi.org/10.7769/gesec.v4i3.275.

Todorov, M. C. A., Kniess, C. T., \& Martins, C. B. (2013a). Competências de Gerentes de Projetos Sustentáveis. Revista de Gestão e Projetos-GeP, 4(3), 98-118. http://dx.doi.org/10.5585/gep.v4i3.206. 
van der Vaart, T., Pieter van Donk, D., Gimenez, C., \& Sierra, V. (2012). Modelling the integrationperformance relationship: collaborative practices, enablers and contextual factors.

International Journal of Operations \& Production Management, 32(9), 1043-10.

http://dx.doi.org/10.1108/01443571211265693.

Vezzoni, G., Júnior, A. C. P., Junior, A. L. B., \& Silva, S. L. (2013). Identificação e Análise de Fatores Críticos de Sucesso em Projetos. Revista de Gestão e Projetos-GeP, 4(1), 116-137. http://dx.doi.org/10.5585/gep.v4i1.83.

Vieira, J. O., \& Zuin, D. C. (2015). Secretariado Executivo no Brasil: profissão ou ocupação? Revista de Gestão e Secretariado, 6(3), 21-45. http://dx.doi.org/10.7769/gesec.v6i3.341.

Winch, G. M. (2014). Three domains of project organising. International Journal of Project Management, 32(5), 721-731. http://dx.doi.org/10.1016/j.ijproman.2013.10.012. 
APPENDIX A - CONSTRUCTS

\begin{tabular}{|c|c|c|c|c|c|c|}
\hline Constructs & $\begin{array}{l}\text { Theoretical or } \\
\text { Constitutive } \\
\text { Definition }\end{array}$ & $\begin{array}{l}\text { Operational } \\
\text { Definition }\end{array}$ & Source & Variables & Means & $\begin{array}{l}\text { Standard } \\
\text { Deviation }\end{array}$ \\
\hline \multirow{11}{*}{$\begin{array}{l}\text { Technical } \\
\text { Competences of } \\
\text { the ES }\end{array}$} & \multirow{11}{*}{$\begin{array}{l}\text { The acquired } \\
\text { professional } \\
\text { knowledge } \\
\text { represents a deep } \\
\text { methodological } \\
\text { knowledge of } \\
\text { processes and } \\
\text { procedures in } \\
\text { activities of the } \\
\text { organization. }\end{array}$} & \multirow{11}{*}{$\begin{array}{c}\text { Project } \\
\text { managers } \\
\text { believe that the } \\
\text { ES has technical } \\
\text { competences. }\end{array}$} & \multirow{11}{*}{$\begin{array}{l}\text { CNE, 2005 } \\
\text { (Brasil, } \\
\text { 2005); } \\
\text { Brière et al } \\
\text { (2015) } \\
\text { Bernhardt } \\
\text { (2004). }\end{array}$} & $\begin{array}{l}\text { TC_ES_1. Capacity to articulate } \\
\text { knowledge according to the } \\
\text { competence levels set by the } \\
\text { organizations. }\end{array}$ & 4.36 & .864 \\
\hline & & & & $\begin{array}{l}\text { TC_ES_10. General vision of } \\
\text { the organization and unique } \\
\text { hierarchical and inter-sector } \\
\text { relations. }\end{array}$ & 4.39 & .914 \\
\hline & & & & $\begin{array}{c}\text { TC_ES_11. Practice of } \\
\text { managerial functions, with a solid } \\
\text { domain of planning, organization, } \\
\text { control, and direction. }\end{array}$ & 4.11 & 1.122 \\
\hline & & & & $\begin{array}{l}\text { TC_ES_2. Use of logical, } \\
\text { critical, and analytical } \\
\text { thinking, dealing with values } \\
\text { and establishing formal and } \\
\text { causal relationships between } \\
\text { phenomena and } \\
\text { organizational situations. }\end{array}$ & 4.23 & 1.034 \\
\hline & & & & $\begin{array}{c}\text { TC_ES_3. Ability to deal with } \\
\text { innovative managerial } \\
\text { models. }\end{array}$ & 4.12 & 1.039 \\
\hline & & & & $\begin{array}{l}\text { TC_ES_4. Mastering the } \\
\text { resources of expression and } \\
\text { communication compatible } \\
\text { with the function assignment, } \\
\text { including negotiation } \\
\text { processes and interpersonal } \\
\text { and intergroup } \\
\text { communication. }\end{array}$ & 4.39 & 1.025 \\
\hline & & & & $\begin{array}{l}\text { TC_ES_5. Effective use of } \\
\text { secretarial techniques, with } \\
\text { new technologies, printing } \\
\text { security, credibility, and } \\
\text { loyalty in the information flow }\end{array}$ & 4.55 & .810 \\
\hline & & & & $\begin{array}{l}\text { TC_ES_6. Adoption of } \\
\text { alternative means related to } \\
\text { improving the quality and } \\
\text { productivity of services, } \\
\text { identifying needs, and } \\
\text { equating solutions }\end{array}$ & 4.21 & 1.004 \\
\hline & & & & $\begin{array}{l}\text { TC_ES_7. Information } \\
\text { management, ensuring } \\
\text { uniformity and reference for } \\
\text { different users }\end{array}$ & 4.35 & .979 \\
\hline & & & & $\begin{array}{c}\text { TC_ES_8. Manage } \\
\text { administrative staff based on } \\
\text { objective, departmental, and } \\
\text { corporate goals. }\end{array}$ & 4.32 & .975 \\
\hline & & & & $\begin{array}{l}\text { TC_ES_9. Capacity for } \\
\text { maximization and optimization } \\
\text { of technological resources }\end{array}$ & 4.19 & 1.023 \\
\hline \multirow{7}{*}{$\begin{array}{l}\text { Behavioral } \\
\text { Competences of } \\
\text { the ES }\end{array}$} & \multirow{7}{*}{$\begin{array}{l}\text { Competence } \\
\text { acquired both in } \\
\text { professional and } \\
\text { life experience. } \\
\text { Ability to manage } \\
\text { daily situations. }\end{array}$} & \multirow{7}{*}{$\begin{array}{l}\text { Project manager } \\
\text { believes that the } \\
\text { ES has behavioral } \\
\text { competences. }\end{array}$} & \multirow{7}{*}{$\begin{array}{l}\text { CNE, 2005 } \\
\text { (Brasil, 2005) }\end{array}$} & $\begin{array}{l}\text { BC_ES_1. Responsiveness } \\
\text { and leadership to teamwork in } \\
\text { the pursuit of synergy }\end{array}$ & 4.44 & 1.003 \\
\hline & & & & BC_ES_2. Initiative & 4.71 & .693 \\
\hline & & & & BC_ES_3. Creativity & 4.53 & .794 \\
\hline & & & & BC_ES_4. Determination & 4.73 & .664 \\
\hline & & & & BC_ES_5. Desire to learn & 4.68 & .738 \\
\hline & & & & BC_ES_6. Openness to change & 4.51 & .760 \\
\hline & & & & $\begin{array}{l}\text { BC_ES_7. Awareness of } \\
\text { implications and ethical } \\
\text { responsibilities in professional } \\
\text { practice. }\end{array}$ & 4.67 & .759 \\
\hline
\end{tabular}


APPENDIX A - Continued...

\begin{tabular}{|c|c|c|c|c|c|c|}
\hline Constructs & $\begin{array}{l}\text { Theoretical or } \\
\text { Constitutive } \\
\text { Definition }\end{array}$ & $\begin{array}{l}\text { Operational } \\
\text { Definition }\end{array}$ & Source & Variables & Means & $\begin{array}{l}\text { Standard } \\
\text { Deviation }\end{array}$ \\
\hline \multirow{4}{*}{$\begin{array}{l}\text { Technical } \\
\text { competences of } \\
\text { project team }\end{array}$} & \multirow{4}{*}{$\begin{array}{c}\text { Technical } \\
\text { competence is } \\
\text { related to } \\
\text { techniques used by } \\
\text { the professionals } \\
\text { of the projects and } \\
\text { involves domain of } \\
\text { knowledge areas in } \\
\text { the project } \\
\text { management, } \\
\text { besides tools and } \\
\text { methods. }\end{array}$} & \multirow{4}{*}{$\begin{array}{l}\text { Technical } \\
\text { competences of } \\
\text { the Project team } \\
\text { are developed } \\
\text { by the ES in } \\
\text { project } \\
\text { management. }\end{array}$} & \multirow{4}{*}{$\begin{array}{l}\text { IPMA Brasil } \\
\text { (2012). }\end{array}$} & $\begin{array}{c}\text { TC_PM_1. Quality } \\
\text { management }\end{array}$ & 4.00 & 1.230 \\
\hline & & & & TC_PM_10. Team work & 4.47 & .859 \\
\hline & & & & $\begin{array}{l}\text { TC_PM_11. Communication } \\
\text { in multiple levels. }\end{array}$ & 4.39 & .914 \\
\hline & & & & TC_PM_12. Troubleshooting. & 4.40 & .900 \\
\hline \multirow{11}{*}{$\begin{array}{c}\text { Contextual } \\
\text { competences of } \\
\text { project } \\
\text { management }\end{array}$} & \multirow{11}{*}{$\begin{array}{l}\text { Contextual } \\
\text { competence } \\
\text { involves } \\
\text { understanding the } \\
\text { context in which } \\
\text { the project is } \\
\text { inserted and the } \\
\text { needs in the field } \\
\text { of portfolio } \\
\text { management, } \\
\text { programs } \\
\text { resources, legal, } \\
\text { environmental and } \\
\text { health aspects, as } \\
\text { well as business } \\
\text { models, finance, } \\
\text { and operation of } \\
\text { the company. }\end{array}$} & \multirow{11}{*}{$\begin{array}{l}\text { Contextual } \\
\text { competences of } \\
\text { the Project team } \\
\text { are developed } \\
\text { by the ES in } \\
\text { project } \\
\text { management. }\end{array}$} & \multirow{11}{*}{$\begin{array}{l}\text { IPMA Brasil } \\
\text { (2012). }\end{array}$} & $\begin{array}{c}\text { CC_PM_13. Orientation to } \\
\text { projects }\end{array}$ & 3.65 & 1.289 \\
\hline & & & & $\begin{array}{c}\text { CC_PM_14. Orientation to } \\
\text { programs }\end{array}$ & 3.80 & 1.284 \\
\hline & & & & $\begin{array}{c}\text { CC_PM_15. Orientation to } \\
\text { portfolios }\end{array}$ & 3.67 & 1.245 \\
\hline & & & & $\begin{array}{c}\text { CC_PM_2. Implementation of } \\
\text { Projects, programs and } \\
\text { portfolios }\end{array}$ & 3.51 & 1.309 \\
\hline & & & & $\begin{array}{c}\text { CC_PM_3. Permanent } \\
\text { organization }\end{array}$ & 4.47 & .844 \\
\hline & & & & CC_PM_4. Business & 3.92 & 1.148 \\
\hline & & & & $\begin{array}{c}\text { CC_PM_5. Systems, products } \\
\text { and e technology }\end{array}$ & 3.64 & 1.226 \\
\hline & & & & $\begin{array}{c}\text { CC_PM_6. People } \\
\text { management }\end{array}$ & 4.16 & 1.091 \\
\hline & & & & $\begin{array}{c}\text { CC_PM_7. Health, security } \\
\text { and environment }\end{array}$ & 3.73 & 1.189 \\
\hline & & & & $\begin{array}{c}\text { CC_PM_8. Finances and } \\
\text { accounting }\end{array}$ & 3.87 & 1.057 \\
\hline & & & & CC_PM_9. Legal aspects & 3.69 & 1.208 \\
\hline \multirow{11}{*}{$\begin{array}{c}\text { Behavioral } \\
\text { Competences of } \\
\text { the Project } \\
\text { Team }\end{array}$} & \multirow{11}{*}{$\begin{array}{l}\text { Behavioral } \\
\text { competences are } \\
\text { related to the } \\
\text { successful } \\
\text { management of } \\
\text { projects and the } \\
\text { parties involved. } \\
\text { They are personal } \\
\text { skills of the project } \\
\text { manager. }\end{array}$} & \multirow{11}{*}{$\begin{array}{l}\text { Behavioral skills } \\
\text { of the project } \\
\text { team are } \\
\text { developed by } \\
\text { ES in project } \\
\text { management. }\end{array}$} & \multirow{11}{*}{$\begin{array}{l}\text { IPMA Brasil } \\
\text { (2012). }\end{array}$} & BC_PM_1. Leadership & 4.19 & 1.182 \\
\hline & & & & $\begin{array}{c}\text { BC_PM_10. Commitment and } \\
\text { innovation }\end{array}$ & 4.45 & 1.082 \\
\hline & & & & BC_PM_11. Self-control & 4.36 & 1.098 \\
\hline & & & & BC_PM_2. Assertiveness & 4.43 & 1.002 \\
\hline & & & & BC_PM_3. Casualness & 4.19 & 1.159 \\
\hline & & & & BC_PM_4. Openness & 4.19 & 1.099 \\
\hline & & & & BC_PM_5. Creativity & 4.32 & 1.08 \\
\hline & & & & $\begin{array}{l}\text { BC_PM_6. Orientation to } \\
\text { results }\end{array}$ & 4.40 & 1.04 \\
\hline & & & & BC_PM_7. Efficiency & 4.52 & .978 \\
\hline & & & & BC_PM_8. Negotiation & 4.16 & 1.079 \\
\hline & & & & BC_PM_9. Ethics & 4.53 & 1.004 \\
\hline
\end{tabular}

